\title{
PENDIDIKAN KARAKTER DI MASYARAKAT
}

\author{
Ahmad Zainuri \\ Universitas Islam Negeri Raden Fatah Palembang \\ E-mail: ahmadzainuri_uin@radenfatah.ac.id
}

\begin{abstract}
Society (society) is a group of people who form a semi-closed (or semi-open) system, where most interactions are between individuals in the group. The variety of education received by students in this community is very much. These include the formation of habits, formation of knowledge, attitudes and interests, as well as moral and religious formation. Education in community education can be said to be indirect education, education carried out unconsciously by the community. And the students themselves consciously or not, they have educated themselves, strengthening their faith and self-confidence in the values of morality and religion in society. That is, the community environment influences the development of students. The influence given by the environment is intentional and accidental. That is, the environment has no specific intentions in influencing the development of students. And the community environment is very influential for children's character development. If the child is in a good community environment, it will also have a good influence on the development of the child's character. Likewise, on the other hand a bad environment can also have a bad influence on children's character development. As parents, they must be smart and smart to choose a good environment for their children, because it will determine the child's character development. Character education as an effort to develop character is an effort made by the world of education to help students understand, care and act in accordance with ethical values. The purpose of character education is to form characters that are implemented in the subject's essential values with the behaviors and attitudes they have. In this case the formation of character, there must be educational networks. Especially in information technology and telecommunications today, one of the factors that have a huge influence on development or vice versa is the destruction of the character of society or the nation is mass media, especially electronic media, with the main actors being television. Actually the magnitude of the role of the media, especially print and radio media, is in the development of national character. The mass media plays a dual role. On the one hand, playing public service advertisements or touching advertisements, on the other hand broadcasts programs/soap operas which actually show negative things, which ultimately are not shunned, instead
\end{abstract}

imitated by the audience. The media must be controlled by the state. The state has an obligation to control all media activities, so that they are in accordance with the goals of the country itself. The legal instruments must be clear and fair. Indonesia itself has a Depkominfo, but only regulates frequency policies, broadcasting rights, and so on. More specifically, there is the Indonesian Broadcasting Commission (KPI), which was formed more independently, but recognized by the government. KPI is expected to be able to filter media activities (especially television) to suit the country's goals, norms, culture, customs, and of course religion. However, until now, the KPI is considered to be still quite weak in acting (filtering), and so than that, it is very necessary (strength) of the participation of the community in controlling these media.

Keywords: Education, Character, Community.

Abstrak: Masyarakat (society) adalah sekelompok orang yang membentuk sebuah sistem semi tertutup (atau semi terbuka), di mana sebagian besar interaksi adalah antara individu-individu yang berada dalam kelompok tersebut. Corak ragam pendidikan yang diterima anak didik dalam masyarakat ini sangat banyak sekali. Di antaranya pembentukan kebiasaan, pembentukan pengetahun, sikap dan minat, maupun pembentukan kesusilaan dan keagamaan. Pendidikan dalam pendidikan masyarakat ini boleh dikatakan pendidikan secara tidak langsung, pendidikan yang dilaksanakan secara tidak sadar oleh masyarakat. Dan anak didik sendiri secara sadar atau tidak, ia telah mendidiknya sendiri, mempertebal keimanan serta keyakinan sendiri akan nilai-nilai kesusilaan dan keagamaan di dalam masyarakat. Artinya, lingkungan masyarakat memberikan pengaruh terhadap perkembangan peserta didik. Pengaruh yang diberikan oleh lingkungan ada yang bersifat sengaja dan bersifat tidak sengaja. Artinya, lingkungan tidak ada kesengajaan tertentu di dalam memberikan pengaruhnya kepada perkembangan anak didik. Dan lingkungan masyarakat sangat berpengaruh bagi perkembangan karakter anak. Bila anak berada pada lingkungan masyarakat yang baik, maka akan dapat memberikan pengaruh yang baik pula bagi perkembangan karakter anak. Begitu pula, sebaliknya lingkungan yang tidak baik juga dapat memberikan pengaruh yang tidak baik bagi 
perkembangan karakter anak. Sebagai orang tua harus jeli dan pintar-pintar memilihkan lingkungan yang baik bagi anaknya, karena akan menentukan perkembangan karakter anak. Pendidikan karakter sebagai upaya pengembangan karakter adalah upaya yang dilakukan dunia pendidikan untuk membantu anak didik supaya mengerti, peduli dan bertindak sesuai dengan nilai-nilai etika. Tujuan pendidikan karakter adalah untuk pembentukan karakter yang terimplementasi dalam nilai-nilai esensial si subyek dengan perilaku dan sikap hidup yang dimilikinya. Dalam hal ini pembentukan karakter, haruslah ada educational networks. Apalagi di teknologi informasi dan telekomunikasi sekarang ini, salah satu faktor yang berpengaruh sangat besar dalam pembangunan atau sebaliknya juga perusak karakter masyarakat atau bangsa adalah media massa, khususnya media eletronik, dengan pelaku utamanya adalah televisi. Sebenarnya besarnya peran media, khususnya media cetak dan radio, dalam pembangunan karakter bangsa. Media massa berperan ganda. Di satu sisi, memutarkan iklan-iklan layanan masyarakat atau iklan yang menyentuh hati, di sisi lain menyiarkan acara/sinetron yang justru malah menampilkan hal-hal negatif, yang akhirnya bukannya dijauhi, malah ditiru oleh para penontonnya. Media-media harus dikontrol oleh negara. Negara memiliki kewajiban untuk mengontrol segala aktivitas media, agar sesuai dengan tujuan negara itu sendiri. Perangkat hukumnya harus jelas dan adil. Indonesia sendiri mempunyai Depkominfo, tapi hanya sekedar mengatur kebijakan frekuensi, hak siar, dan sebagainya. Lebih khusus lagi,ada KPI (Komisi Penyiaran Indonesia), yang dibentuk lebih independen, namun diakui pemerintah. KPI diharapkan dapat memfilter aktivitas media (terutama televisi) agar sesuai dengan tujuan negara, norma, kebudayaan, adat, dan tentunya agama. Namun sampai saat ini, KPI dirasa masih cukup lemah dalam bertindak (memfilter), dan maka daripada itu, sangat dibutuhkan (kekuatan) peran serta masyarakat dalam mengontrol mediamedia tersebut.

Kata Kunci: Pendidikan, Karakter, Masyarakat.

\section{Pendahuluan}

Masyarakat (sebagai terjemahan

istilah society) adalah sekelompok orang yang membentuk sebuah sistem semi tertutup (atau semi terbuka), di mana sebagian besar interaksi adalah antara individu-individu yang berada dalam kelompok tersebut. Kata "masyarakat" sendiri berakar dari kata dalam bahasa Arab, musyarak. Lebih abstraknya, sebuah masyarakat adalah suatu jaringan hubungan-hubungan antar entitas-entitas.
Masyarakat adalah sebuah komunitas yang interdependen (saling tergantung satu sama lain). Umumnya, istilah masyarakat digunakan untuk mengacu sekelompok orang yang hidup bersama dalam satu komunitas yang teratur.

Menurut Syaikh Taqyuddin An-Nabhani, sekelompok manusia dapat dikatakan sebagai sebuah masyarakat apabila memiliki pemikiran, perasaan, serta sistem atau aturan yang sama. Dengan kesamaan-kesamaan tersebut, manusia kemudian berinteraksi antar sesama mereka berdasarkan kemaslahatan.

Sementara itu, para pakar sosiologi, mengartikan masyarakat, sebagai berikut; 1). Selo Sumardjan masyarakat adalah orang-orang yang hidup bersama danmenghasilkan kebudayaan; 2). Karl Marx masyarakat adalah suatu struktur yang menderita suatu keteganganorganisasi atau perkembangan akibat adanya pertentangan antara kelompok-kelompok yangterbagi secara ekonomi; 3). Emile Durkheim masyarakat merupakan suatu kenyataan objektif pribadi-pribadi yang merupakan anggotanya; 4). Paul B. Horton \& C. Hunt masyarakat merupakan kumpulan manusia yang relatif mandiri, hidup bersama-sama dalam waktu yang cukup lama, tinggal di suatu wilayah tertentu,mempunyai kebudayaan sama serta melakukan sebagian besar kegiatan di dalam kelompok /kumpulan manusia tersebut; 5). Horton dan Hunt (2006:59) mendefinisikan masyarakat sebagai sekumpulan manusia yang secara relatif mandiri, yang secara bersama-sama cukup lama, yang mendiami suatu wilayah tertentu, memiliki kebudayaan yang sama, dan melakukan sebagian besar kegiatannya dalam kelompok tersebut; 6). Mac Iver dan Page, mengatakan bahwa, "masyarakat adalah suatu sistem kebiasaan dan tata cara, dari wewenang dan kerjasama antara berbagai kelompok dan penggolongan, dan pengawasan tingkah laku serta kebiasaan-kebiasaan manusia; 7). Ralph Linton mengatakan bahwa, "masyarakat merupakan kelompok manusia yang telah hidup dan bekerja bersama cukup lama sehingga dapat mengatur diri mereka dan menganggap diri mereka sebagai sesuatu kekuatan sosial dengan batas-batas yang dirumuskan dengan jelas"; 8). J.1. Gillin dan J.P. Gillin mengatakan bahwa masyarakat adalah kelompok manusia yang terbesar dan mempunyai kebiasaan, tradisi, sikap dan perasaan persatuan yang sama; dan 9). M.J. Herskovits mengemukakan bahwa masyarakat adalah 
kelompok individu yang diorganisasikan dan mengikuti satu cara hidup tertentu.

Sedangkan faktor atau unsur-unsur terbentuk sebuah masyarakat, menurut Soerjono Soekanto setidaknya memuat unsur sebagai berikut ini;1). Berangotakan minimal dua orang; 2). Anggotanya sadar sebagai satu kesatuan; 3). Berhubungan dalam waktu yang cukup lama yang menghasilkan manusia baru yang saling berkomunikasi dan membuat aturan-aturan hubungan antar anggota masyarakat; dan 4). Menjadi sistem hidup bersama yang menimbulkan kebudayaan serta keterkaitan satu sama lain sebagai anggota masyarakat.

Masyarakat juga sering diorganisasikan berdasarkan cara utamanya dalam bermata pencaharian. Pakar ilmu sosial mengidentifikasikan ada; masyarakat pemburu, masyarakat pastoral nomadis, masyarakat bercocok tanam, dan masyarakat agrikultural intensif, yang juga disebut masyarakat peradaban.Sebagian pakar menganggap masyarakat industridan pasca-industri sebagai kelompok masyarakat yang terpisah dari masyarakat agrikultural tradisional. Masyarakat dapat pula diorganisasikan berdasarkan struktur politiknya; berdasarkan urutan kompleksitas dan besar, terdapat masyarakat band, suku, chiefdom, dan masyarakat negara.

Sebagian pakar sosologi juga ada yang mengatakan bahwa masyarakat dalam bahasa Inggris disebut society berasal dari bahasa Latin, societas, yang berarti hubungan persahabatan dengan yang lain. Societas diturunkan dari kata socius yang berarti teman, sehingga arti society berhubungan erat dengan kata sosial. Secara implisit, kata society mengandung makna bahwa setiap anggotanya mempunyai perhatian dan kepentingan yang sama dalam mencapai tujuan bersama.

Bila dilihat dari definisi di atas dapat dikatakan bahwa masyarakat merupakan sekelompok individu yang saling tergantung sama lain yang diatur oleh sistem aturan yang mengikat sebagai sebuah komunitas. Hal ini disebabkan manusia merupakan makhluk yang memiliki keinginan untuk menyatu dengan sesamanya serta alam lingkungan di sekitarnya. Dengan menggunakan pikiran, naluri, perasaan, dan keinginan manusia memberi reaksi dan melakukan interaksi dengan lingkungannya.

\section{Pembahasan}

\section{Hubungan Timbal Balik Masyarakat Terhadap Karakter Anak}

Seperti dijelaskan di atas, masyarakat merupakan kumpulan sekelompok orang yang mempunyai adat istiadat, kebiasaan sikap, perilaku dan kebudayaan, tentunya akan berpengaruh terhadap pembentukan karakter manusia atau anak didik. Sebab manusia atau anak didik adalah bagian dari masyarakat. Karenanya, lembaga pendidikan masyarakat merupakan lembaga pendidikan ke tiga setelah keluarga dan sekolah. Pendidikan ini telah dimulai sejak anak-anak untuk beberapa jam sehari lepas dari asuhan keluarga dan berada di luar sekolah.

Corak ragam pendidikan yang diterima anak didik dalam masyarakat ini sangat banyak sekali. Di antaranya pembentukan kebiasaan, pembentukan pengetahun, sikap dan minat, maupun pembentukan kesusilaan dan keagamaan. Pendidikan dalam pendidikan masyarakat ini boleh dikatakan pendidikan secara tidak langsung, pendidikan yang dilaksanakan secara tidak sadar oleh masyarakat. Dan anak didik sendiri secara sadar atau tidak, ia telah mendidiknya sendiri, mempertebal keimanan serta keyakinan sendiri akan nilai-nilai kesusilaan dan keagamaan di dalam masyarakat.

Berdasarkan Undang-undang Nomor 20 tahun 2003 tentang Sistem Pendidikan Nasional, peristiwa pendidikan yang berlangsung pada lingkungan masyarakat, tergolong pada pendidikan non formal. Lembaga pendidikan non formal atau pendidikan luar sekolah (LPS) ialah semua bentuk pendidikan yang diselenggarakan dengan sengaja, tertib, dan berencana, dilaksanakan di luar kegiatan persekolahan.

Sementara Klies Russel (1974) dalam Djuju Sudjana (1989) menyatakan bahwa pendidikan non formal mencakup setiap kegiatan pendidikan yang sistematis dan bertujuan, yang biasanya dilaksanakan diluar sistem persekolahan, di dalamnya memuat komponen isi atau materi, satuan waktu, kriteria masuk, staf dan lain-lain, yang dipilih sesuai dengan situasi, kondisi serta potensi yang dimilik warga belajar untuk mencapai tujuan belajar.

Di sinilah, lingkungan masyarakat memberikan pengaruh terhadap perkembangan peserta didik. Pengaruh yang diberikan oleh lingkungan ada yang bersifat sengaja dan bersifat tidak sengaja. Artinya, lingkungan tidak ada 
kesengajaan tertentu di dalam memberikan pengaruhnya kepada perkembangan anak didik. Dan lingkungan masyarakat sangat berpengaruh bagi perkembangan karakter anak. Bila anak berada pada lingkungan masyarakat yang baik, maka akan dapat memberikan pengaruh yang baik pula bagi perkembangan karakter anak. Begitu pula, sebaliknya lingkungan yang tidak baik juga dapat memberikan pengaruh yang tidak baik bagi perkembangan karakter anak. Sebagai orang tua harus jeli dan pintar-pintar memilihkan lingkungan yang baik bagi anaknya, karena akan menentukan perkembangan karakter anak.

Tentunya sebagai makhluk sosial, sejak dini anak memang sebaiknya dikenalkan pada lingkungan masyarakat. Dalam proses perkembangan anak, lingkungan merupakan faktor yang sangat penting setelah pembawaan. Tanpa adanya dukungan dari faktor lingkungan, maka proses perkembangan dalam mewujudkan potensi pembawaan menjadi kemampuan nyata tidak akan terjadi.

Oleh karena itu, fungsi atau peranan lingkungan ini dalam proses perkembangan dapat dikatakan sebagai faktor ajar, yaitu faktor yang akan mempengaruhi perwujudan suatu potensi secara baik atau tidak baik, sebab pengaruh lingkungan dalam hal ini dapat bersifat positif yang berarti pengaruhnya baik dan sangat menunjang perkembangan suatu potensi atau bersifat negatif yaitu pengaruh lingkungan itu tidak baik dan akan menghambat atau merusak perkembangan. Sebab itu, sudah menjadi tugas utama orang tua dan pendidik untuk menciptakan atau menyediakan lingkungan yang positif agar dapat menunjang perkembangan anak dan berusaha untuk mengawasi dan menghindarkan pengaruh faktor lingkungan yang negatif yang dapat menghambat dan merusak perkembangan anak.

Lingkungan masyarakat bisa juga disebut sebagai lingkungan sosial, lingkungan tempat tinggal anak berinteraksi dengan orang lain yang lebih luas lagi. Anak adalah bagian dari masyarakat yang saling berinteraksi satu sama lain di mana anak dapat memberikan pengaruh pada lingkungannya. Sebaliknya, anak juga dapat menerima pengaruh dari lingkungan masyarakat tersebut. Misalnya, lingkungan tempat tinggal di asrama polisi atau tentara, anak-anak yang tinggal di sana cenderung lebih berani karena mereka merasakan adanya label dari orang tuanya.
Lingkungan yang seperti ini akan membentuk karakter anak menjadi keras, pribadi yang galak, apa yang ia inginkan harus segera terlaksana. Ataupun dengan memilih tinggal di tengah-tengah kota besar, yang mana sesama tetangga tak saling mengenal satu sama lain, lingkungan yang seperti ini dapat membentuk karakter yang tidak baik juga pada anak. Anak jadi terbiasa untuk tidak peka terhadap orang lain, merasa tidak memerlukan orang lain dalam hidupnya, sikap individualismenya juga akan sangat terlihat.

Demikian pula sebaliknya, misalnya, dengan memilih tinggal di sebuah perkampungan di pinggiran kota. Yang di lingkungan tersebut terdapat masjid, para remajanya pun aktif dan antusias dalam kegiatan-kegiatan syiar agama untuk masyarakat sekitar, baik orangtua, remaja bahkan anak-anak kecil. Suasana lingkungan menjadi hidup, dinamis, agamis, harmonis serta menyenangkan hati masyarakat yang tinggal di lingkungan tersebut. Anak-anak terbentuk karakter yang sopan santun, beradaptasi, berempati, serta dapat menjadi manusia yang berjiwa sosial.

Oleh sebab itu, peran serta masyarakat hendaknya didayagunakan karena dapat membantu pelaksanaan pendidikan, baik dalam bentuk pembinaan moral, bakat, pengajaran, maupun budaya. Dalam menjalin kerjasama dengan masyarakat hendaknya dilandasi semangat kebersamaan dan tanggungjawab. Dan sejatinya, sekolah berkorelasi positif dengan masyarakat sebab bagaimana pun sekolah adalah milik masyarakat, karena raw input sekolah itu sendiri berasal dari masyarakat, dan output sekolah nantinya akan kembali kepada masyarakat.

Jadi, masyarakat ikut menaruh kepentingan dan bertanggungjawab terhadap kelangsungan penyelenggaraan pendidikan di satuan-satuan pendidikan baik secara langsung maupun tidak langsung. Beberapa bentuk hubungan lembaga pendidikan dengan masyarakat antara lain yaitu;

1. Mengikutsertakan warga sekolah dalam kegiatan kemasyarakatan, seperti kesenian, perayaan hari nasional dan keagamaan, pelestarian lingkungan hidup, dan lain sebagainya. Dengan melakukan kegiatan ini, ada banyak manfaat yang dapat dipetik, selain mengembangkan semangat pembinaan bagi peserta didik, aktivititas sekolah dan masyarakat juga mampu menyatu. Jadi masyarakat sekitar sekolah merasa ikut memiliki sekolah, sehingga sewaktu-waktu sekolah membutuhkan bantuan, 


\section{Hasil Penelition}

masyarakat sekitar pun tidak segan-segan menolong. Contohnya peran keamanan sekolah yang turut dibantu masyarakat sekitar.

2. Penyediaan fasilitas sekolah untuk keperluan masyarakat, contohnya penggunaan aula, lapangan olahraga, dan lain-lain. Dengan mempersilakan masyarakat sekolah menggunakan fasilitas sekolah (dengan tetap memperhatikan pertimbangan-pertimbangan tertentu), nantinya selain menumbuhkan kerukunan antara sekolah dengan masyarakat sekitar juga dapat diambil manfaat lainnya. Misalnya, pembinaan olahraga, dapat dibantu oleh masyarakat sekitar (tidak hanya oleh guru olahraga).

3. Mendayagunakan tokoh-tokoh potensial dalam masyarakat guna menunjang pendidikan baik secara langsung maupun tidak langsung.

4. Mengikutsertakan POMG/Komite Sekolah dalam menunjang pelaksanaan pendidikan tanpa menambah beban yang memberatkan. Contohnya jika ada seorang wali murid yang memiliki kemampuan lebih di bidang kesenian, ia dapat membantu guru kesenian mengajar di kelas maupun di luar kelas (ekstrakurikuler).

5. Menjalin hubungan dengan instansi lain, seperti sekolah lain, instansi pemerintah terkait (dinas pendidikan, dinas kesehatan dan lain-lain), instansi swasta; perusahaan komersil. Ada banyak manfaat yang dapat diambil sekolah dengan menjalin hubungan dengan instansi pemerintah terkait, seperti dinas kesehatan. Misalnya dalam bentuk penyuluhanpenyuluhan, pemberian obat-obatan, dan lain sebagainya. Adapun jika dengan instansi swasta, misalnya memberikan informasi lowongan kerja bagi sekolah, dan lain sebagainya.

Mengacu pada berbagai bentuk hubungan lembaga pendidikan dengan masyarakat sekitar, dapat ditarik garis besar bahwa bidang kerjasama dapat meliputi pembinaan moral, bakat, pengajaran, dan budaya. Di antara kesemua bentuk hubungan kerjasama ini, akan lebih baik jika sekolah sangat memperhatikan pada hubungan kerjasama sekolah dengan orangtua atau wali peserta didik. Hal ini dikarenakan wali peserta diidk yang paling memiliki kesamaan tanggung jawab dan tujuan dengan sekolah.

Dalam konteks pendidikan karakter, Thomas Lickona mengatakan bahwa pengembangan karakter adalah upaya yang dilakukan dunia pendidikan untuk membantu anak didik supaya mengerti, peduli dan bertindak sesuai dengan nilainilai etika. Tujuan pendidikan karakter adalah untuk pembentukan karakter yang terimplementasi dalam nilai-nilai esensial si subyek dengan perilaku dan sikap hidup yang dimilikinya.

Dari kematangan karakter inilah, kualitas seorang pribadi diukur. Mengutip apa yang dikemukakan Foerster (dalam Doni Koesoema), ada empat karakter yang harus dimiliki manusia yang berkualitas, yakni; pertama, keteraturan interior di mana setiap tindakan diukur berdasar hierarki nilai. Ini artinya setiap tindakan yang dilakukan haruslah berpedoman pada nilai-nilai yang berlaku pada masyarakat diwilayah itu sebagai hukum tak tertulis untuk dipatuhi. Tindakan yang bertentangan dengan nilai-nilai sebagai pedoman normatif yang berlaku akan menimbulkan pertentangan dan perlawanan dari masyarakat yang menunjung nilai-nilai sebagai pandangan hidupnya.

Kedua, adanya koherensi. Maksudnya, adanya motivasi yang memberi keberanian pada seseorang untuk membuat keputusan yang tepat, dengan dilandasi dengan kekuatan memegang prinsip dan tidak takut pada risiko yang ditimbulkannya dan sebagai dasar dalam membangun kepercayaan satu sama lain.

Ketiga, otonomi, yakni adanya nilai-nilai kepribadian yang terinternalisasi dari aturan-aturan yang berlaku. Pengambilan keputusan dan tindakan yang tidak mudah dipengaruhi oleh orang lain.

Keempat, keteguhan dan kesetiaan. Keteguhan merupakan daya tahan seseorang guna mengingini apa yang dipandang baik. Dan kesetiaan merupakan dasar bagi penghormatan atas komitmen yang dipilih.

Kematangan keempat karakter inilah menurut Foerster, yang memungkin seseorang melewati tahap individualitas menuju personalitas, yang menentukan performance seorang pribadi terhadap tindakannya. Tidak dinyana lagi bahwa pendidikan karakter melibatkan berbagai lembaga yang bertanggung jawab dalam pendidikan itu sendiri.

Dalam kaitanya dengan pembentukan karakter, haruslah ada educational networks antara lembaga-lembaga pendidikan yang sempat terputus. Keluarga sebagai lembaga pertama dan utama dalam pembentukan karakter, sebagaimana yang dikemukakan Phillips (2000) hendaknya menjadi school of love. Dalam persepektif Islam keluarga sebagai school of love dapat terimplementasikan dalam bentuk madrasah mawaddah wa rahmah 
(Azyumardi Azra, 2002). Islam memberikan perhatian besar dalam pembinaan keluarga (usrah). Berangkat dari keluarga yang mawaddah dan warrahmah, anak-anak memiliki modal dasar berupa potensi untuk melaksanakan pembelajaran di sekolah. Lembaga sekolah bukan hanya sebagai lembaga transfer of knowledge, tetapi bagaimana sekolah dapat memberikan pembelajaran yang berorientasi pada nilai-nilai (values oriented enterprise) baik estetika maupun etika (ahlak, moral dan budipekerti).

Lembaga pendidikan yang memberikan kontribusi dalam pembentukan karakter (estetika dan etika) adalah masyarakat. Dari perspektif Islam menurut Quraish Shihab (dalam Azyumardi Azra,2002), mengatakan, situasi kemasyarakatan dengan sistem nilai yang dianutnya, mempengaruhi sikap dan cara pandang masyarakat secara keseluruhan. Lebih lanjut dikatakan, hal ini akan muncul ajaran tentang amar ma'ruf dan nahy munkar dan fardhu kifayah, tanggungjawab bersama dalam menegakan nilai-nilai yang baik dan mencegah nilai-nilai yang buruk.

\section{Media Massa, Negara dan Pendidikan Karakter}

Dalam era kemajuan teknologi informasi dan telekomunikasi sekarang ini, salah satu faktor yang berpengaruh sangat besar dalam pembangunan atau sebaliknya juga perusak karakter masyarakat atau bangsa adalah media massa, khususnya media eletronik, dengan pelaku utamanya adalah televisi. Sebenarnya besarnya peran media, khususnya media cetak dan radio, dalam pembangunan karakter bangsa telah dibuktikan secara nyata oleh para pejuang kemerdekaan. Bung Karno, Bung Hatta, Ki Hajar Dewantoro, melakukan pendidikan bangsa untuk menguatkan karakter bangsa melalui tulisan-tulisan di surat kabar waktu itu. Bung Karno dan Bung Tomo mengobarkan semangat perjuangan, keberanian dan persatuan melalui radio. Mereka dalam keterbatasannya, memanfaatkan secara cerdas dan arif teknologi yang ada pada saat itu untuk membangun karakter bangsa, terutama sekali: kepercayaan diri bangsa, keberanian, kesediaan berkorban, dan rasa persatuan.

Sayangnya kecerdasan dan kearifan yang telah ditunjukkan generasi pejuang kemerdekaan dalam memanfaatkan media massa untuk kepentingan bangsa makin sulit kita temukan sekarang. Sebagaimana dipaparkan oleh Gede Raka; "Media massa sekarang memakai teknologi yang makin lama makin canggih. Namun tanpa kecerdasan dan kearifan, media massa yang didukung teknologi canggih tersebut justru akan melemahkan atau merusak karakter bangsa. Saya tidak ragu mengatakan, media elektronik di Indonesia, khususnya televisi, sekarang ini kontribusinya "nihil" dalam pembangunan karakter karakter bangsa. Saya tidak bermaksud untuk mengatakan bahwa tidak ada program televisi yang baik. Namun sebagian besar program televisi justru lebih menonjolkan karakter buruk daripada karakter baik. Seringkali pengaruh lingkungan keluarga yang baik justru dirusak oleh siaran media televisi. Di keluarga, anak-anak dididik untuk menghindari kekerasan, namun acara TV justru penuh dengan adegan kekerasan.

Di rumah, anak dididik untuk hidup sederhana, namun acara sinetron di televisi Indonesia justru memamerkan kemewahan. Di rumah anak-anak dididik untuk hidup jujur, namun tayangan di televisi Indonesia justru secara tidak langsung menunjukkan "kepahlawanan"tokohtokoh yang justru di mata publik dianggap "kasare atau "pangeran-pangeran" koruptor. Para guru agama mengajarkan bahwa membicarakan keburukan orang lain dan bergosip itu tidak baik, namun acara televisi, khususnya infotainment, penuh dengan gosip. Bapak dan ibu guru di sekolah mendidik para murid untuk berperilaku santun, namun suasana sekolah di sinetron Indonesia banyak menonjolkan perilaku yang justru tidak santun dan melecehkan guru. Secara umum, banyak tanyangan di televisi Indonesia, justru „membongkare anjuran berperilaku baik yang ditanamkan di rumah oleh orang tua dan oleh para guru di sekolah" (Raka, 2007: 4).

Media massa berperan ganda. Di satu sisi, memutarkan iklan-iklan layanan masyarakat atau iklan yang menyentuh hati, di sisi lain menyiarkan acara/sinetron yang justru malah menampilkan halhal negatif, yang akhirnya bukannya dijauhi, malah ditiru oleh para penontonnya. Media-media harus dikontrol oleh negara. Negara memiliki kewajiban untuk mengontrol segala aktivitas media, agar sesuai dengan tujuan negara itu sendiri. Perangkat hukumnya harus jelas dan adil. Indonesia sendiri mempunyai Depkominfo, tapi hanya sekedar mengatur kebijakan frekuensi, hak siar, dan sebagainya. Lebih khusus lagi,ada KPI (Komisi Penyiaran Indonesia), yang dibentuk lebih independen, namun diakui pemerintah. KPI diharapkan dapat memfilter aktivitas media 
(terutama televisi) agar sesuai dengan tujuan negara, norma, kebudayaan, adat, dan tentunya agama. Namun sampai saat ini, KPI dirasa masih cukup lemah dalam bertindak (memfilter), dan maka daripada itu, sangat dibutuhkan (kekuatan) peran serta masyarakat dalam mengontrol mediamedia tersebut (Raka, 2007)

Dari pengaruh media massa tersebut, maka ke depan perlu dipikirkan kembali fungsi media massa sebagai media edukasi yang memiliki "cultural of power" dalam membangun masyarakat yang berkarakter, karena efek media massa sangat kuat dalam membentuk pola pikir dan pola perilaku masyarakat. Prinsip-prinsip dalam pendidikan karakter perlu diinternalisasikan dalam programprogram yang ditanyakan oleh media massa, sebagai bentuk tanggung jawab bersama dalam mengatasi krisis karakter bangsa. Pengelola media massa perlu untuk mengembangkan dirinya sebagai "agen perubahan" yang mimiliki jiwa yang berkarakter, sehingga seni dan karya yang dihasilkan dan ditayangkan akan sarat dengan nilainilai kebajikan, nilai-nilai kemanusiaan, nilai-nilai humanis-religius dan dijauhkan dari tayangan yang merusak moral bangsa, dan "virus-virus" yang melemahkan etos dan budaya kerja .

Pembangunan karakter tidak hanya untuk sebuah idealisme namun hal ini juga hendaknya memiliki makna nyata dalam membangun kesejahteraan hidup bangsa Indonesia. Pembangunan karakter pada tataran individu dan tataran masyarakat luas perlu dikuatkan agar bangsa Indonesia lebih mampu cepat meningkatkan kesejahteraan masyarakat Indonesia (Raka,2007:1).“Karakter yang perlu diperbaiki adalah kedisiplinan. Bangsa Indonesia telah dikenal dengan bangsa dengan jam karetnya, jika tidak terlambat maka dianggap bukan orang Indonesia. Disiplin nasional perlu digalakkan dengan sungguhsungguh dalam upaya mewujudkan masyarakat, bangsa, negara yang bercita-cita luhur. Disiplin bertujuan memperbaiki tingkah laku dan moral bagi seluruh manusia yang tinggal di Indonesia, baik bagi kalangan akademisi dan juga para pelaku bisnis di Indonesia. Pengertian disiplin adalah disiplin kerja, disiplin cara hidup sehat, disiplin berlalu-lintas, sanitasi, pelestarian lingkungan. Disiplin nasional berhasil jika individu melaksanakan disiplin tersebut dengankesungguhan hati dan memahami bahwa disiplin diri merupakan cikal bakal untuk disiplin nasional. Dengan demikian, dengan adanya pendidikan karakter, budaya dan moral bukan hanya generasi yang telah menjadi guru, tetapi juga setiap anak, pemuda, dan orang dewasa yang ada di Indonesia dapatmelaksanakannya dengan sebaik-baiknya. Melalui pendidikan karakter, pendidikan budaya, dan pendidikan moral akan menghasilkan watak dan manusia Indonesia yang seutuhnya. Di satu sisi, pihak pemerintah berusaha dengan gigih untuk memberikan teladan bagi warga masyarakat" (Raka,2007: 3).

Negara memiliki tanggung jawab moral untuk melakukan pendidikan karakter, budaya, dan moral bangsa Indonesia. Hal ini sesuai dengan prinsip sudah ditetapkan baik dalam Undangundang Dasar 1945 maupun dalam Undang-undang Sistem Pendidikan Nasional Nomor 20 tahun 2003. Kurikulum disusun sesuai dengan jenjang pendidikan dalam kerangka Negara Kesatuan Republik Indonesia dengan memperhatikan; peningkatan iman dan takwa; peningkatan akhlak mulia; peningkatan potensi daerah dan lingkungan; tuntutan pembangunan daerah dan nasional; tuntutan dunia kerja; perkembangan ilmu pengetahuan, teknologi, dan seni; agama; dinamika perkembangan global; dan persatuan nasional dan nilainilai kebangsaan.

Kekuatan untuk menjalankan amanah undang-undang sangat ditentukan oleh kekuatan hukum. Hal ini membawa konsekuensi bahwa pembangunan karakter bangsa ini sangat ditentukan oleh perilaku penegak hukum sebagai penjaga ketertiban dan ketentraman dalam kehidupan berbangsa dan bernegara untuk tujuan kesejahteraan, keadilan masyarakat, ketentraman masyarakat.

Oleh karena itu, para penegak hukum haruslah dipegang oleh orang-orang yang berkarakter kuat, demikian juga para elite politik , birokrat, teknokrat yang menjadi menjalankan semua amanah Undang-undang Dasar 1945 pun haruslah orang-orang terplih karena memiliki karakter yang kuat dan tangguh sebagai pemimpin rakyat. Sehingga kedudukan mereka benar-benar kuat sebagai " pejuang bangsa" yang selalu ingin membawa bangsa ini pada kemajuan dan kesejahteraan.

\section{Simpulan}

Masyarakat (society) adalah sekelompok orang yang membentuk sebuah sistem semi tertutup (atau semi terbuka), di mana sebagian besar interaksi adalah antara individu-individu yang 
berada dalam kelompok tersebut. Kata "masyarakat" sendiri berakar dari kata dalam bahasa Arab, musyarak. Lebih abstraknya, sebuah masyarakat adalah suatu jaringan hubunganhubungan antar entitas-entitas. Karenanya, lembaga pendidikan masyarakat merupakan lembaga pendidikan ke tiga setelah keluarga dan sekolah. Pendidikan ini telah dimulai sejak anak-anak untuk beberapa jam sehari lepas dari asuhan keluarga dan berada di luar sekolah.

Corak ragam pendidikan yang diterima anak didik dalam masyarakat ini sangat banyak sekali. Di antaranya pembentukan kebiasaan, pembentukan pengetahun, sikap dan minat, maupun pembentukan kesusilaan dan keagamaan. Pendidikan dalam pendidikan masyarakat ini boleh dikatakan pendidikan secara tidak langsung, pendidikan yang dilaksanakan secara tidak sadar oleh masyarakat. Dan anak didik sendiri secara sadar atau tidak, ia telah mendidiknya sendiri, mempertebal keimanan serta keyakinan sendiri akan nilai-nilai kesusilaan dan keagamaan di dalam masyarakat.

Di sinilah, lingkungan masyarakat memberikan pengaruh terhadap perkembangan peserta didik. Pengaruh yang diberikan oleh lingkungan ada yang bersifat sengaja dan bersifat tidak sengaja. Artinya, lingkungan tidak ada kesengajaan tertentu di dalam memberikan pengaruhnya kepada perkembangan anak didik. Dan lingkungan masyarakat sangat berpengaruh bagi perkembangan karakter anak. Bila anak berada pada lingkungan masyarakat yang baik, maka akan dapat memberikan pengaruh yang baik pula bagi perkembangan karakter anak. Begitu pula, sebaliknya lingkungan yang tidak baik juga dapat memberikan pengaruh yang tidak baik bagi perkembangan karakter anak. Sebagai orang tua harus jeli dan pintar-pintar memilihkan lingkungan yang baik bagi anaknya, karena akan menentukan perkembangan karakter anak.

Dalam konteks pendidikan karakter dimaknai sebagai upaya pengembangan karakter adalah upaya yang dilakukan dunia pendidikan untuk membantu anak didik supaya mengerti, peduli dan bertindak sesuai dengan nilai-nilai etika. Tujuan pendidikan karakter adalah untuk pembentukan karakter yang terimplementasi dalam nilai-nilai esensial si subyek dengan perilaku dan sikap hidup yang dimilikinya. Dalam hal ini pembentukan karakter, haruslah ada educational networks.
Dalam era kemajuan teknologi informasi dan telekomunikasi sekarang ini, salah satu faktor yang berpengaruh sangat besar dalam pembangunan atau sebaliknya juga perusak karakter masyarakat atau bangsa adalah media massa, khususnya media eletronik, dengan pelaku utamanya adalah televisi. Sebenarnya besarnya peran media, khususnya media cetak dan radio, dalam pembangunan karakter bangsa. Media massa berperan ganda. Di satu sisi, memutarkan iklaniklan layanan masyarakat atau iklan yang menyentuh hati, di sisi lain menyiarkan acara/sinetron yang justru malah menampilkan halhal negatif, yang akhirnya bukannya dijauhi, malah ditiru oleh para penontonnya. Media-media harus dikontrol oleh negara. Negara memiliki kewajiban untuk mengontrol segala aktivitas media, agar sesuai dengan tujuan negara itu sendiri. Perangkat hukumnya harus jelas dan adil. Indonesia sendiri mempunyai Depkominfo, tapi hanya sekedar mengatur kebijakan frekuensi, hak siar, dan sebagainya. Lebih khusus lagi,ada KPI (Komisi Penyiaran Indonesia), yang dibentuk lebih independen, namun diakui pemerintah. KPI diharapkan dapat memfilter aktivitas media (terutama televisi) agar sesuai dengan tujuan negara, norma, kebudayaan, adat, dan tentunya agama. Namun sampai saat ini, KPI dirasa masih cukup lemah dalam bertindak (memfilter), dan maka daripada itu, sangat dibutuhkan (kekuatan) peran serta masyarakat dalam mengontrol mediamedia tersebut.

\section{Daftar Pustaka}

Lickona,

dkk. 2007.

Dalamhttp://alenmarlissmpn1 gresik.wordpress .com/2010/10/03/ manfaat-karakteristikpendidikan-bagi-guruuntukmembangunperadaban bangsa/

Lickona, Thomas, 1991.Educating for Character : Hoe Our School Can Do Teach Respect and Responsibility,New York; Brantam Book

Lickona, Thomas, 1999. Eleven Principle of Effective Character, Scholastic Early Childhood To day, November/December 1998, 13.1, PreQuest Education Journals.

Lickona, Thomas, Schaps, Eric, dan Lewis,Catherine, 2007. Eleven Principles of Effective Character Education. Character Education Partnership

Raka, Gede, 2006. “Guru Tranformasional Dalam Pembangunan Karakter dan Pembangunan 
Bangsa", Makalah, Orasi Dosen Berpretasi Tingkat Poltekes dan Tingkat Nasional, Jakarta: 10 Nopember 2006.

Raka, Gede, 2006."Pendidikan Untuk Kehidupan Bermakna". Makalah, Orasi Ilmiah pada Hari Wisuda Universitas Kristen Maranatha Bandung, 25 Maret 2006

Raka, Gede, 2006."Pendidikan Untuk Kehidupan Bermakna". Makalah, Orasi Ilmiah pada Hari Wisuda Universitas Kristen Maranatha Bandung, 25 Maret 2006

Raka, Gede, 2007."Pendidikan Membangun Karakter”. Makalah, Orasi Perguruan Taman Siswa,

Raka, Gede, 2007."Pendidikan Membangun Karakter”. Makalah, Orasi Perguruan Taman Siswa.

Ralqis. 2009. "Faktor-faktor yang Mempengaruhi Perkembangan" Dalam http://www.duniaremaja.org/t154-faktorfaktor-yang-mempengaruhi-perkembangan, di akses tanggal 14 April 2011). 